\title{
Controle Social: REFORMANDO A ADMINISTRAÇÃO PARA A SOCIEDADE
}

Francisco Carlos da Cruz Silva*

\author{
RESUMO
}

sse artigo é uma síntese da trabalho vencedor do 10 lugar no concurso de monografias do Tribunal de Contas da União - Prêmio Serzedello Corrêa - Versão 2001. O trabaIho tem como objetivo evidenciar os mecanismos de controle da Administração Pública Federal com a implantação do modelo gerencial (pós-burocrático), fazendose uma avaliação das condições da sociedade brasileira para exercer o controle social. Assim, busca-se caminhar na direção de criar um pensamento crítico sobre o tema e propor medidas concretas de ação em resposta à seguinte questão: Quais as perspectivas para o controle social no Brasil? São analisados aspectos administrativos, culturais, políticos, sociais e históricos envolvidos. Conclui-se que o principal alicerce para o controle efetivo da administração pública, considerado na reforma gerencial em curso, seria o controle social, porém a análise de aspectos da formação cultural e política de nossa sociedade demonstram que a mesma não está preparada para exercer essa tarefa. Além disso, há fortes evidências de existirem deficiências pelo lado da Administração. Diante desse dilema, são propostas linhas de ação, considerando o estágio atual de implementação da reforma, que possam produzir mudanças na Administração e trazer perspectivas de melhoria das condições para o exercício do controle social. As linhas de ação envolvem os seguintes pontos: Valorização do Controle Social na estratégia de mudança; Criação de canais de atuação para controle social; Melhoria de capacitação e cultura no serviço público; Desenvolvimento e padronização de indicadores de desempenho; e Uniformização e integração dos sistemas de informação.

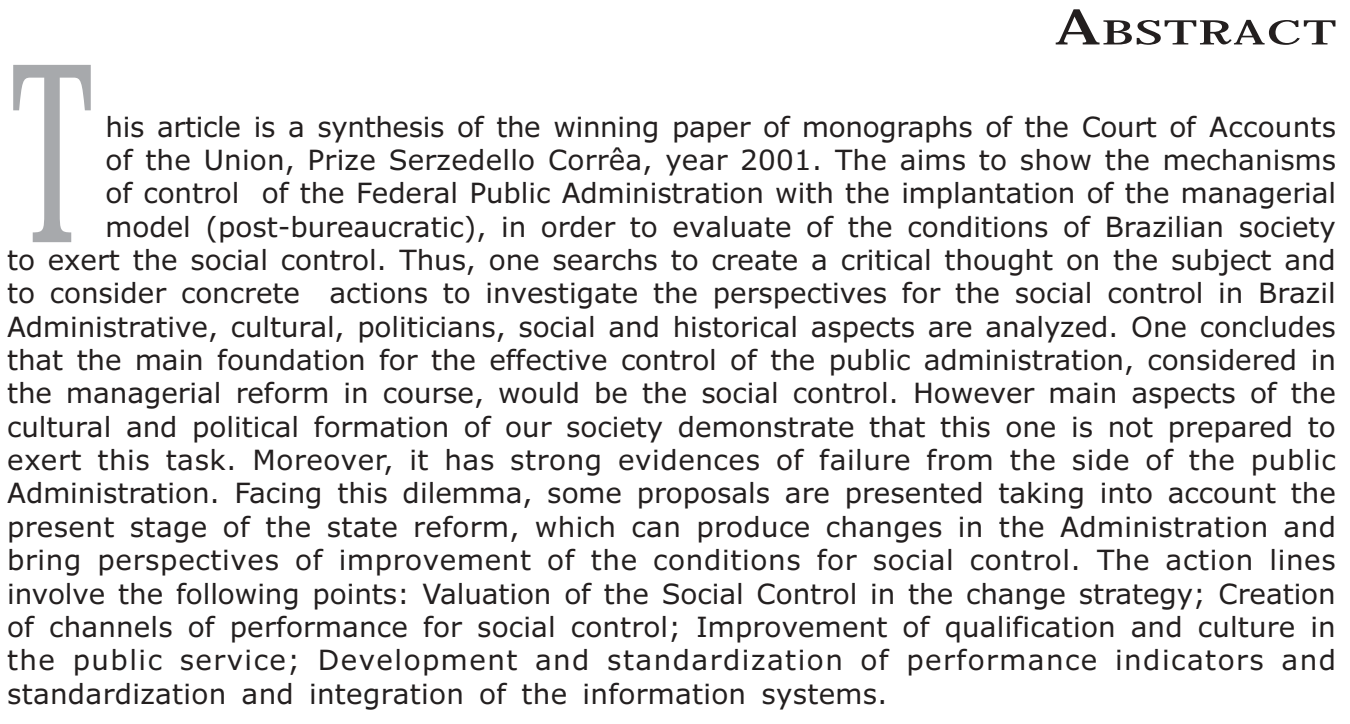

*Analista de Finanças e Controle da Controladoria-Geral da União e Mestre em Administração pela Escola de Administração da Universidade Federal da Bahia 
sociedade brasileira e a classe política e dirigente não têm-se dado conta da grande necessidade de implementação de mudanças nos sistemas de controle sobre os recursos públicos, ampliando-se os meios de controle social. Esse aumento do controle não pode, entretanto, significar a imobilização da ação do gestor público, mas a garantia de uma utilização mais racional, eficiente, transparente, regular e compatível com o esforço de submissão da sociedade à tributação imposta pelo Estado.

O cenário atual de ampla disputa política, diante das transformações sociais do final do século XX e início do século XXI, tem exposto as fragilidades dos modelos existentes. As mudanças necessárias no controle devem caminhar na direção de ampliação e consolidação da democracia no Brasil. O controle social na aplicação dos recursos públicos colocados à disposição do Estado é um tema extremamente importante para ser discutido. As transformações decorrentes de reformas administrativas têm caminhado na direção de ampliação do controle social, entretanto ainda são tímidos os meios disponíveis para a sociedade, além do despreparo do cidadão.

Nos últimos anos, o País tem se defrontado com inúmeros casos de desvios e impropriedades na execução do gasto público. Muitas Comissões Parlamentares de Inquérito (CPI's) foram criadas a fim de esclarecer casos de corrupção ${ }^{1}$ e desmandos na Administração Pública por práticas neopatrimoniais. Esses fatos impõem a urgência de uma discussão profunda sobre o tema controle, pois acumula-se um elevado custo social pela má utilização de recursos públicos.

A corrupção é um fenômeno social presente mesmo em nações mais desenvolvidas e com mecanismos de controle do Estado bastante elaborados. A existência de corrupção no Brasil ou em qualquer outro País poderia ser justificada e aceita como um processo natural, baseando-se nesse argumento. Porém, quando existem evidências de que a sua prática atinge níveis que a sociedade não mais tolera, é necessário uma reavaliação nas formas de controle da Administração Pública com o objetivo de coibir a sua ocorrência.

A imprensa, exercendo um papel relevante para a transparência das ações públicas, tem-se encarregado de tornar público uma série de acontecimentos que resultaram ou parecem resultar na perda de grandes volumes de recursos arrecadados pelo governo. Os Tribunais de Contas e o Ministério Público têm tido uma ação fundamental na condução desses casos, mas isso não parece ser suficiente para inibir novos abusos. Dentre os casos mais famosos de desvio ou má utilização de recursos públicos, pode-se citar o caso dos "anões do orçamento", os desvios para liberação de recursos federais via contas fantasmas durante o governo Collor, o superfaturamento no Prédio do Superior Tribunal de Justiça, o escândalo da Previdência. $\mathrm{E}$, recentemente, os casos do superfaturamento na construção do prédio do Tribunal do Trabalho em São Paulo, da ajuda do Banco Central aos Bancos Marka e Fontcidam, dos indícios de omissão culposa na fiscalização de contas CC5 pelo Banco Central, e, ainda, do caso da cobrança de propinas pela máfia dos fiscais em São Paulo. Como se pode perceber o fenômeno não é um privilégio do poder executivo, ele ocorre também nos legislativo e judiciário. Além disso, não se restringe à esfera Federal, é presente também na esfera estadual e municipal.

A modificação estrutural por meio do ideário da Reforma Gerencial, introduzida no Brasil altera as formas de controle da Administração Pública, visa a ênfase nos resultados e tem como base as possibilidades do controle social. Porém, num País como o Brasil, onde ainda existe uma grande parcela da população que vive à margem dos direitos sociais e políticos, falar em controle social parece um contra-senso. 
O objetivo deste estudo é analisar as perspectivas do controle social da administração especialmente com a introdução da Reforma Gerencial. Espera-se desenvolver um pensamento crítico a respeito do tema e introduzir propostas práticas dentro do modelo atual que sirvam como base de discussão.

O controle social atuante pode representar o elemento essencial para assegurar que o governo atinja os objetivos estabelecidos para os órgãos públicos e para os programas de longa duração com eficiência, efetividade e dentro dos preceitos legais da ordem democrática. É fundamental uma análise criteriosa, considerando não só os aspectos da administração, mas, principalmente, os aspectos políticos e sociais envolvidos. Assim, há de se levar em conta as dificuldades da sociedade e a existência de distorções como a corrupção e as práticas neopatrimoniais no Estado Brasileiro.

Apesar de todos esses problemas, é importante deixar claro que a necessidade da discussão em torno do tema controle se impõe, não somente por causa das impropriedades e corrupção existentes na Administração Pública, mas fundamentalmente a fim de garantir que existam elementos e dispositivos, dentro do ciclo de gestão, que propiciem os ajustes necessários nas políticas públicas para uma aplicação mais eficiente e transparente dos recursos públicos, sendo isso o que a sociedade espera.

Considerando os fatos apresentados, este trabalho tenta caminhar na direção de criar um pensamento crítico e propor medidas concretas em resposta à seguinte questão: Quais as perspectivas para o controle social no Brasil? Sem, contudo, ter a intenção ser exaustivo na discussão do tema.

\section{U m Conceito Abrangente}

Conceituar Controle Social nos reporta a uma análise do ponto de vista semântico e a uma avaliação dos dispositivos jurídicos existentes.

O sentido da palavra controle assume diversas conotações dependendo da forma e do contexto em que é utilizada. A palavra controle é de origem francesa (controlê) e foi introduzida no Direito Brasileiro por Seabra Fagundes em sua monografia O Controle dos Atos Administrativos pelo Poder Judiciário em 1941 (Meirelles, 1995). Na língua portuguesa, a palavra tem um sentido de dominação e, talvez por essa causa, o controle é muitas vezes visto como um procedimento inconveniente e inoportuno

Na Administração Pública, o controle é imprescindível desde que os recursos em jogo não são particulares e sim públicos, assim devem estar comprometidos com os interesses e objetivos de toda uma Nação. Quando se junta à palavra controle o termo "social", dá-se um sentido da origem do controle, portanto o controle social seria um controle de origem no social, ou melhor, na sociedade. $\mathrm{Na}$ verdade qualquer controle tem origem na sociedade que é a quem se devem reportar todos os entes que a representam.

O controle é uma das funções administrativas que já era previsto no paradigma da administração científica que fundamenta a Escola Clássica iniciada por Fayol e Taylor. Essas funções administrativas eram: planejar, organizar, comandar, coordenar e controlar. Ao longo dos últimos anos, mesmo com todas as transformações no estudo da teoria da administração, chegando ao estudo da Teoria das Organizações num sentido mais amplo, o tema controle tem sido cada vez mais enfatizado como uma necessidade para se conseguir resultados.

O controle do Estado, em sentido amplo, se dá de várias formas dentre as quais se pode destacar o controle do próprio poder do Estado por meio do sistema de freios e contrapesos, concebido originalmente por Montesquieu, e consubstanciado, no nosso ordenamento jurídico, pela separação dos poderes e independência dos mesmos prevista no art. 2ํ da Constituição Federal de 1988. Além disso, existem diversos dispositivos constitucionais que têm o objetivo de controle 
das ações do Estado e dos gestores públicos, no exercícios de suas atribuições. Esse controle abrange, não apenas, os atos do poder executivo, mas todos os atos dos três poderes quando exercendo atividades administrativas.

A finalidade do controle é garantir que a administração atue de acordo com os princípios explícitos e implícitos na Constituição Federal que são: legalidade, moralidade, finalidade pública, motivação, impessoalidade, publicidade e, mais recentemente introduzido, o princípio da eficiência.

Segundo Di Pietro (1998:478), o controle da Administração Pública é

"o poder de fiscalização e correção que sobre ela exercem os órgãos dos poderes Judiciário, Legislativo e o Executivo, com o objetivo de garantir a conformidade de sua atuação com os princípios que Ihes são impostos pelo ordenamento jurídico".

Este conceito é, sem dúvida, um conceito formal. Ele não prevê, explicitamente, o controle direto pela sociedade como forma de controle da administração. No entanto, como explica a própria autora, o controle da administração pode, também, ser exercido pela sociedade, mediante a participação dos cidadãos de forma individual ou coletiva. Porém, do ponto de vista legal o que a sociedade faz é apenas provocar os órgãos competentes da própria administração, que tem um poder-dever, atribuído pela lei, com finalidade corretiva. Esse poder-dever não pode ser renunciado nem retardado sob pena de responsabilidade de quem se omitiu.

A evolução nas formas de interação ou associação entre o setor privado e público exigirá modificação desses instrumentos legais com a expansão da participação da sociedade. A descentralização das atribuições do Estado impõe a necessidade de uma participação cada vez maior da sociedade no controle da administração. É o que tem sido denominado de controle social (Loureiro e Fingermann, 1992).

Apesar de cada vez mais utilizado nas discussões que se referem à Administração Pública, controle social é um conceito com origem na sociologia. LaPiere (1954) faz uma larga construção sobre controle social em seu Livro $A$ Theory of Social Control. A base desse trabalho está na redescoberta dos grupos primários da sociedade como elementos-chave no estabelecimento das normas de conduta sociais. A ação desses grupos orientam indiretamente os objetivos globais da sociedade. Essa ação de grupos primários, não necessariamente planejada, que modifica a conduta social por meio de um sistema dinâmico de punições é o que se chama de controle social. Entretanto, esse conceito de controle social elaborado na sociologia tem características muito diversas do conceito que tem sido utilizado para o estudo da Administração Pública.

Segundo Viegas (1996), o estudo do tema controle na administração tem tido pouca receptividade. Isso se deve, justamente, ao fato do termo haver sido importado da sociologia. Esse fato, por um lado, transfere o estudo para a área de origem e, por outro lado, afasta os analistas em razão da conotação negativa do vocábulo que seria comportamental e punitiva. O autor alerta das conseqüências da transposição acrítica de conceitos na vida das organizações.

No estudo aqui desenvolvido, o que interessa é entender a conotação do termo controle social que tem sido dada na análise do processo de restruturação administrativa no Brasil. Nesse sentido, em muitos trabalhos recentemente escritos (Santos e Cardoso, 2001, Di Pietro, 1998, Bresser Pereira, 1998, Cunill Grau, 1996, Loureiro e Fingermann, 1992), pode-se identificar que o termo controle social tem se referido à possibilidade de atuação dos grupos sociais (sociedade civil) por meio de qualquer uma das vias de participação democrática no controle das ações do Estado e dos gestores públicos. Esse conceito amplo de controle social, que tem um caráter positivo de atuação da democracia é que será considerado na discussão aqui proposta.

Com base no conceito de controle, pode-se indicar cinco objetivos principais dos sistemas de controle nas organizações em geral e, especialmente, na Administração Pública, adaptando-se o proposto por Edelman e Aparício (1992). 
O primeiro objetivo é o de proteger os ativos da organização dos erros intencionais ou não e das irregularidades que se possam produzir. Como segundo objetivo, tem-se a obtenção de informações corretas e seguras que permitam a tomada de decisões acertadas tanto no âmbito interno como no externo. O terceiro objetivo é o de conseguir adesão às políticas gerais da organização. O quarto objetivo visa a atingir as metas e programas da organização. Finalmente, o quinto e último grande objetivo é promover a eficiência e eficácia nas operações da organização por meio de uma utilização racional dos recursos disponíveis. Esse objetivo está vinculado com todos os anteriores. A proteção dos ativos da organização aliada a um conjunto de informações corretas e seguras, a adesão às políticas gerais e o cumprimento de metas e programas levam a uma utilização mais racional e, portanto, mais eficiente dos recursos.

O controle da Administração Pública surge dessa necessidade de correção de rumos frente aos interesses da sociedade, que foram legitimados nas propostas dos candidatos vencedores nas eleições, e da obrigação ética de utilização regular dos recursos públicos.

\section{Controle Social entre as ESPÉCIES DE CONTROLE}

Os controles possíveis da Administração Pública são, por vezes, classificados em espécies que dependem do critério utilizado na elaboração da classificação. Segundo Di Pietro (1998:478-538), os critérios são variados e exprimem as possibilidades e tipos de controle que se pode exercer na administração conforme mostra-se a seguir.

O critério de classificação mais geral é baseado na identificação do órgão que exerce o controle. Assim, o controle pode ser: administrativo, se realizado por órgão administrativo, legislativo, se exercido pelo legislativo ou judicial, se exercido por órgão judiciário. Dessas possibilidades do controle em cada poder, nasce outro critério de classificação. Dependendo se o controle partir de um órgão interno ou não à estrutura do ente controlado, ele pode ser classificado em interno ou externo. Já quanto ao momento em que se realiza, o controle ainda classificado como: prévio ou a priori, concomitante e posterior ou a posteriori.

O modelo gerencial traz a noção de outro critério de classificação de controle. Esse critério se relaciona com o critério visto no parágrafo anterior, mas não se confunde com ele. A distinção é feita com base na ênfase que se dá aos processos ou ao resultado da gestão. Assim, o controle poderia ser de processo ou de resultados. O controle de processos caracterizariar-se-ia pela ênfase na análise dos processos e por pouca ou nenhuma vinculação com os resultados a serem atingidos. Já o controle de resultados, busca sempre objetivos mais amplos da organização, priorizando os resultados.

Bresser Pereira (1998), em seu livro Reforma do Estado para a Cidadania, faz uma exposição sobre mecanismos e formas de controle no modelo gerencial. Segundo ele, pode-se fazer uma simplificação a partir de uma perspectiva institucional e, assim, afirmar que existem três mecanismos de controle fundamentais: o Estado, o mercado e a sociedade civil. No Estado está incluído o sistema legal. O mercado é o sistema econômico. E a sociedade civil está estruturada pelos grupos sociais. Utilizando-se do critério funcional, o autor estabelece o que ele chama de formas de controle que são: o controle hierárquico ou administrativo, que se exerce dentro das organizações públicas ou privadas; o controle democrático ou social, que se exerce em termos políticos sobre as organizações e os indivíduos; e o controle econômico via mercado. Nessa perspectiva, o controle hierárquico pode ser gerencial, burocrático ou tradicional. O controle democrático pode-se dar por meio da democracia representativa ou democracia direta, ou seja, o controle social. 


\section{Controle Social no Contexto da Reforma Administrativa de 1995}

Apesar de ter-se buscado, na Constituição de 1988, um sistema de controle consistente com uma burocracia weberiana e capaz de garantir a aplicação dos recursos públicos de forma regular, muitos problemas ainda permaneceram após essa data. Pode-se relacionar vários motivos pelos quais os controles formais estabelecidos continuaram e continuam ineficazes.

Muitos gestores públicos se utilizam de brechas da lei para usurpar e realizar a malversação do dinheiro público. Os órgãos de controle interno criados não possuem autonomia suficiente para aplicar a Lei e conseguir responsabilizar os gestores, coibindo a corrupção. Uma grande parcela de servidores públicos em postos importantes e de grande responsabilidade dentro do governo, tanto na gestão como na fiscalização da aplicação de recursos, ingressaram no serviço público antes da exigência de concurso público e não tem capacitação suficiente, além de serem mal remunerados e desmotivados.

Além de tudo isso, percebe-se que a Administração Pública brasileira incorpora uma característica patrimonialista que se sobrepôs ao modelo burocrático esculpido na Constituição de 1998. O governo não dispõe de estrutura e recursos, inclusive de informação, adequados à atividade de controle prevista, fato que se foi amenizando no decorrer da década de 90 . Falta integração entre os órgãos de controle interno de cada poder e entre esses e o controle externo. Falta agilidade e rigor dos Tribunais de Contas no julgamento das contas dos gestores ocasionadas muitas vezes por ingerências políticas, mas, essencialmente, por falhas na instrução dos processos de contas analisados. A política do jeitinho e a ineficácia da aplicação da lei torna a possibilidade de responsabilização do gestor público pouco provável no Brasil, criando um ambiente favorável ao descontrole. Todos esses fatores associados contribuem para a pouca eficácia dos controles formais e a Administração Pública continua prestando serviços de pouca qualidade e com baixa eficiência.

A partir de 1990, a modificação do contexto político pela transição democrática, a eleição direta do Presidente da República, além de outros fatores, como a necessidade de reduzir custos e aumentar a qualidade dos serviços num mercado cada vez mais competitivo, o desenvolvimento tecnológico, a globalização das economias mundiais, a introdução de conceitos neoliberais e a grande rigidez dos princípios estabelecidos na Constituição Federal de 1988, trazem a necessidade do estudo de um novo padrão para a Administração Pública no Brasil (ENAP/MARE, 1995).

Em 1994, é criada a Secretaria de Reforma do Estado, no âmbito do MARE Ministério da Administração e Reforma do Estado, a qual estabelece em 1995 o Plano Diretor da Reforma do Aparelho do Estado que introduz uma série de diretrizes a serem desenvolvidas dentro da Administração Pública brasileira visando à consolidação de um modelo "gerencial" ou "pós-burocrático".

O argumento básico para a proposta de Reforma, naquele momento, é que há uma crise no Estado por força do modelo de desenvolvimento adotado por governos anteriores. Assim, o Estado ter-se-ia desviado das suas funções básicas para ampliar sua presença no setor produtivo e isso teria acarretado uma deterioração dos serviços públicos e o agravamento da crise fiscal, tendo por conseqüência a elevação da inflação, sendo, desse modo, uma ameaça para a estabilidade econômica do País conseguida com o Plano Real.

Além disso, a elevação do custo da máquina pública é diagnosticada como sendo resultado dos benefícios a servidores públicos e pelos excessivos controles, controles a priori característicos da administração burocrática, consolidados na Constituição de 1988. Esses benefícios e controles estariam emperrando e reduzindo a eficiência da administração, fazendo com que o Estado se voltasse para si mesmo e para os interesses corporativos dos funcionários públicos. 
Com esses argumentos, a Reforma do Estado passou a ser colocada como um instrumento indispensável para consolidar a estabilidade e assegurar o crescimento sustentado da economia. Para solucionar a crise do Estado e elevar a eficiência administrativa é proposta a implementação do modelo gerencial.

0 modelo gerencial, que emerge em outros países, mais desenvolvidos economicamente que o Brasil, na segunda metade do século XX, difere do modelo burocrático em algumas características. O modelo burocrático clássico é marcado por características tais como impessoalidade, formalismo (legalidade), idéia de carreira, hierarquia e profissionalização. Nesse modelo, o controle é fortemente condicionado pela legalidade e realizado a priori. Já no novo modelo "gerencial", a maioria dessas características da burocracia são mantidas, com exceção do formalismo, ao qual é sugerida a redução, dando-se uma liberdade maior ao gestor público para este expressar a sua criatividade. A autonomia do gestor é aumentada mediante descentralização e, assim, busca-se o controle de resultados. Também, são utilizados vários conceitos e práticas de administração privada aplicadas à Administração Pública, tais como: Reengenharia, Qualidade Total e outros. Entre as mudanças de princípios a serem introduzidas pelo Plano de Reforma, em relação ao modelo burocrático clássico, têm-se a redução dos controles formais, descentralização das funções públicas com a horizontalização das estruturas, elevação da autonomia na gestão, incentivo à criatividade e, ainda, a introdução da competição administrada.

Da mesma forma que a Reforma Burocrática atende a um modelo-racional legal de Administração Pública, A Reforma Gerencial está referida a um modelo gerencial ou da nova gestão pública - new public management (Bresser Pereira, 1998).

A Reforma do Estado também é colocada como um resgate da res pública (Bresser Pereira, 1997), como se pudesse produzir uma elevação do controle social da Administração Pública quando descentraliza e busca uma maior participação da sociedade. A descentralização ou aumento do poder local leva a um aumento do processo democrático que está em curso (Bresser Pereira, 1998). E, ainda, a Reforma procura desenvolver a governança no Estado, tornando o Estado o articulador de recursos de diversas instituições públicas e privadas visando ao desenvolvimento de atividades públicas.

Segundo Bresser Pereira (1998), é necessário uma combinação de mecanismos de mercado, de democracia direta ou controle social e de controle hierárquico ou gerencial. Para o autor, a lógica de controle que orienta a Reforma do Estado tem um caráter histórico, porque parte de uma evolução dos mecanismos de controle que vão do tradicional, nas sociedades primitivas, ao controle gerencial na Reforma do Estado dos anos 90. E, ainda, obedece aos princípios da maior democracia, da maior difusão do poder, ao princípio econômico da eficiência, ao princípio da maior automaticidade dos controles e ao princípio do aumento do espaço público. Assim, o modelo gerencial proposto espera um novo direcionamento para a combinação dos mecanismos de controle. O controle passaria a ser menos administrativo e passaria a ser mais econômico e social.

Sob esses argumentos, o plano de reforma visa à mudança da ênfase no controle formal, a priori de processos e busca a ênfase no controle de resultados e a posteriori. A sociedade, nesse sistema, deverá ter uma participação maior na fiscalização da atuação dos gestores e funcionar como uma forma de controle externo que seria o controle social. O modelo se baseia na hipótese que a obtenção de resultados é conseguida com um controle social atuante que possa apontar os fatos para a responsabilização dos gestores públicos. Maria da Conceição Tavares foi a primeira a chamar a atenção do Ministro Bresser Pereira sobre a importância do controle social durante a fase de elaboração do Plano Diretor (Bresser Pereira, 1998).

A necessidade de estabelecimento de mecanismos automáticos, difusos e eficientes de controle da administração colocam em evidência as possibilidades do controle social (Bresser Pereira, 1998). Assim, por meio de medidas ligadas 
ao Plano de Reforma Administrativa, a possibilidade de controle social passa a incorporar cada vez mais o ordenamento jurídico brasileiro. Em diversas leis e dispositivos normativos e na própria Constituição Federal foram incluídos dispositivos que tentam introduzir possibilidades de maior controle social dos recursos públicos.

A nova concepção institucional da administração é fundamentada na classificação das atividades do Estado e está prevista uma grande importância para os contratos de gestão no controle de elevado volume de recursos nessa nova estrutura. A administração é dividida em quatro níveis de governo, visando a dar mais autonomia na gestão das instituições. De acordo com O Plano Diretor de Reforma do Aparelho do Estado, os níveis de governo são: núcleo estratégico, atividades exclusivas, serviços não-exclusivos, produção de bens e serviços para o mercado. Adotando-se essa estrutura, o objetivo é que as atividades exclusivas de Estado sejam executadas por Agências Autônomas (Executivas ou Reguladoras) na forma de Autarquias e Fundações. Já as atividades não-exclusivas de Estado serão transferidas às Organizações Sociais, entidades privadas qualificadas como tal para executarem as atividades. Em ambos os casos, a ligação com o Núcleo Estratégico dar-se-á via contratos de gestão e as entidades terão autonomia gerencial, financeira e orçamentária. Assim, os indicadores de desempenho definidos nos contratos de gestão serão o instrumento fundamental para o controle dos recursos envolvidos nas transferências para essas entidades descentralizadas, agências autônomas e organizações sociais.

Finalmente, percebe-se, pela análise do modelo gerencial, que o controle dos recursos públicos é uma questão fundamental para o sucesso da Reforma e para a real transformação da Administração Pública brasileira. Isso devido às grandes implicações inseridas nas orientações da Reforma. Segundo Bresser Pereira (1998), a Reforma Gerencial atende a três orientações básicas:

1. Orientação técnica : que percebe a mudança de foco do controle dos procedimentos para o controle de resultados.

2. Orientação Econômica : que identifica o controle por quase-mercados ou competição administrada como o principal instrumento da administração gerencial.

3. Orientação política : que soma aos controles de resultados e de competição administrada, definindo forma de controle direto pela sociedade com uma das principais características da Reforma Gerencial.

Assim, o controle, no modelo gerencial, deixaria de ser principalmente burocrático, de procedimentos, realizado pelo próprio administrador e por órgãos de controle interno e externo e passa a ser estruturado por uma combinação de quatro tipos de controle (Bresser Pereira,1998):

- $\quad$ Controle de resultados, a partir de indicadores de desempenho estipulados nos contratos de gestão.

- $\quad$ Controle contábil de custos, que pode ser entendido como o elemento central do controle de resultados.

- $\quad$ Controle por quase-mercados ou competição administrada.

- $\quad$ Controle social, pelo qual os cidadãos exercitam formas de democracia direta.

Pode-se identificar, na análise das orientações do modelo gerencial, uma série de pressuposições do ambiente que precisariam estar compatíveis com a realidade brasileira para que surtissem os efeitos desejados.

A orientação técnica, com a mudança de foco para os resultados, pressupõe uma capacitação da Administração Pública que só pode ser conseguida a longo prazo. Não é considerada a verdadeira crise que é uma crise de gestão pública como delineada por Nogueira (1997).

A orientação econômica, com o estabelecimento de quase-mercados, pressupõe uma possibilidade de competição em um ambiente altamente dominado pela manipulação política. 
A orientação política, com a previsão teórica de controle social, pressupõe uma sociedade capaz de suprir de forma preponderante a redução dos controles formais. Num ambiente propício para a reestruturação e de forte movimento para o rearranjo do poder dentro do Estado, fica evidente a tendência de dicotomia entre política e administração.

Além disso, tem-se que levar em conta que existem diversas dificuldades em se colocar o próprio modelo gerencial em funcionamento e isso pode significar dificuldades inerentes ao controle. Entre elas: a dificuldade de identificação dos produtos do governo; a dificuldade de avaliação do desempenho das organizações públicas; o fato de que o Estado não pode acionar a si mesmo como no caso das relações privadas; e, finalmente, o que se considera o maior problema, é que o arbítrio gerencial pode levar a uma possível perda de controle dos recursos públicos (Sherped e Valencia, 1996).

A transposição do modelo gerencial, aplicado em países mais desenvolvidos economicamente, sem a devida adequação para o caso brasileiro, é outro problema que precisa ser discutido (Abrucio, 1997).

Di Pietro (1998a) também identifica riscos para o cidadão e para o patrimônio público no processo de Reforma. Sem meios de controle social adequados para as Organizações Sociais, os recursos públicos ficam à disposição dos grupos políticos no poder e distantes do interesse público. As formas previstas de participação dos usuários nas Organizações Sociais na reforma não garantem que haverá uma participação efetiva (Nassuno, 1997). Entende-se que esse aspecto deva ser analisado cuidadosamente (Penteado Filho, 1998), com o objetivo de se viabilizar controles sociais adequados, para que entidades descentralizadas, como as Organizações Sociais, não passem a se reproduzir, simplesmente, pelas facilidades que poderão existir na possibilidade de gastar recursos públicos com ampla autonomia.

Pode-se perceber que a urgência da situação crítica que se encontra a Administração Pública associada à ânsia de se colocar em prática uma proposta inovadora e a forte tendência ao rearranjo do poder dentro do Estado tornaram algumas avaliações da realidade brasileira mais superficiais, trazendo possíveis riscos para a conformação dos sistemas de controle propostos.

O simplismo de alguns enfoques de Reformas Administrativas na América Latina é demonstrado por muitos autores ${ }^{2}$. Esse simplismo, muitas vezes, decorre da dicotomia entre política e administração nos Planos de Reforma. O modelo gerencial puro tem como base a separação entre a política e a administração (Abrucio, 1997).

Entretanto, apesar de tantas questões relevantes acerca dos critérios e condições para implementação da Reforma Administrativa, é ponto pacífico que a Administração Pública brasileira precisaria de uma reformulação. Os traços tradicionais marcaram profundamente a cultura dentro das organizações públicas, gerando ineficiência, clientelismo, nepotismo e outras degenerações que a burocracia não conseguiu debelar. A crise do Estado de Bem Estar Social, a integração econômica com o resto do mundo e o déficit do setor público exigem uma elevação do padrão de eficiência e eficácia das ações públicas.

No livro Reforma do Estado para a cidadania - A Reforma Gerencial brasileira na perspectiva institucional, Bresser Pereira faz uma larga discussão dos mecanismos de controle que ele espera resultem da Reforma. Ele diz:

"Os controles sociais são essenciais na Administração Pública gerencial na medida em que compensam a redução do controle legal de procedimentos e complementam o controle de resultados".

Esse é um ponto fundamental na avaliação, pois demonstra o pressuposto do Plano de Reforma de que o controle social compensará a redução da rigidez

\footnotetext{
2 Em La Reforma de la Administracion publica em América Latina (Kliksberg, 1984) são discutidos vários processos de Reforma Administrativa na América Latina.
} 
burocrática. Baseando-se nesse pressuposto, poder-se-ia concluir que para a manutenção do padrão de controle existente seria necessário que fossem delineados mecanismos de controle social que suprissem de forma concomitante a redução dos controles formais que são retirados por restruturação da administração. Porém, é importante lembrar que controle social não é algo tão fácil de se conseguir. O processo democrático depende de aprendizado. O simples estabelecimento de dispositivos legais e estruturais pode resultar num amontoado de regras e mecanismos inúteis, pois não correspondem às habilidades de cidadania desenvolvidas na sociedade civil brasileira.

A questão que se coloca é: será que as organizações públicas dando resultado e competindo entre si estarão, necessariamente, aplicando os recursos da melhor maneira do ponto de vista social? Sem dúvida que os valores na Administração Pública devem ser outros, diferentes dos princípios da administração privada. Não se pode apenas pensar em resultados, além do que, a competição pode gerar uma guerra de interesses que provoca prejuízos para a Administração Pública. Por esses motivos, o controle social deve ser justamente o fiel da balança. Porém, para que o controle social funcione é preciso uma sociedade preparada para exercer tal função.

Santos e Cardoso (2001) demonstram que as diferenças entre setor público e o setor privado são insuperáveis, sendo que qualquer abordagem isenta da questão tem que considerar esse fato.

\section{Dificuldades no Processo de Reforma}

\section{In Adequação da In Serção Social e Regulação Política}

A revolução gerencial introduz uma série de contribuições à Administração Pública. Entretanto, a sua condição mais ou menos dicotômica varia conforme o contexto social e o segmento da ação pública. No caso brasileiro, a modernização gerencial e a inserção social são requisitos de excelência para as organizações públicas, tendencialmente ortodoxas e insuladas. Porém, a capacidade de inserção social, demonstrada no Brasil, está bastante correspondente com a possibilidade de consolidação de um padrão de representação de interesses sociais em bases neocorporativas (Martins, 1997).

Por outro lado, os riscos decorrentes de uma mudança calcada essencialmente na regulação política são inserções auto-orientadas, o que, na hipótese pessimista, levariam ao neo-insulamento burocrático ou insulamento pós-burocrático. A construção da regulação política em bases racionais é uma tarefa complexa e esbarra nos imperativos fisiológicos da governabilidade e no bloqueio à burocratização política. Nos processos de Reforma Administrativa no Brasil parece haver um hiato entre política e administração (Martins, 1997).

A idéia de autonomia presente no gerencialismo, consubstanciada por redução de controles formais e ausência de estrutura de controle social para suprir a regulação política necessária, produz o risco de um processo de insulamento pós-burocrático. Ou seja, é necessário se imaginar estratégias de controle social que visem a um grau de inserção e regulação consistente com a realidade do Brasil.

\section{PatRIM ONIALISM O PERSISTENTE}

O patrimonialismo persistente em nossa administração tem demonstrado dispositivos de reacomodação aos novos padrões de Administração Pública associados aos processos de Reforma Administrativa, perpetuando disfunções típicas na utilização dos recursos públicos (Pinho, 1998, 1998a). 
No caso da atual Reforma Administrativa, a modificação do controle tem como pressuposto a redução da rigidez burocrática, que pode implicar a diminuição do componente formal da burocracia, abrindo espaço para o crescimento do patrimonialismo ou, melhor, do neopatrimonialismo, assim chamado, por sua existência nas sociedades contemporâneas.

O neopatrimonialismo não é simplesmente uma sobrevivência das estruturas tradicionais em sociedades contemporâneas, mas uma forma bastante atual de dominação política por um "estrato social sem propriedades e que não tem honra social por mérito próprio", ou seja, pela burocracia e pela chamada classe política (Schwartzman, 1988).

No Brasil a formação histórica e social propiciou o ambiente necessário à continuidade do patrimonialismo, conjugado aos novos padrões burocráticos e, possivelmente, aos novos traços do gerencialismo (Pinho, 1998, 1998a). O gerencialismo proposto na Reforma implica redução de controles formais e pode significar diminuir a racionalidade formal da burocracia ou, então, deixar a racionalidade substancial se sobrepor, gerando ambiente para o patrimonialismo.

\section{Evidências de Cultura de Corrupção}

A corrupção é um fenômeno social presente nas organizações públicas e privadas mesmo em nações politicamente mais desenvolvidas e com controles mais elaborados e eficazes (Klitgaard, 1994). A corrupção, por ser uma ameaça potencial de desprestígio das instituições, muitas vezes é relevada a segundo plano (Pinheiro e Vieira, 1993). Entretanto, como foi visto, no Brasil, a formação patrimonialista da administração é fundamentada com base na formação histórica de nosso Estado e sociedade civil (Pinho, 1998, 1998a) e isto resulta necessariamente em possibilidades efetivas de corrupção.

Os casos que freqüentemente circulam na imprensa e têm sido motivo de inúmeras Comissões Parlamentares de Inquérito (CPI's) nos últimos anos indicam que a sociedade não mais tolera os casos de corrupção nos níveis que se apresentam no Estado brasileiro. Talvez o clímax dos processos de patrimonialismo e de corrupção se tenha dado no Governo de Fernando Collor e culminou no seu impeachment. A corrupção, como fenômeno social presente de forma marcante no Brasil, deve ser estudada e considerada com cuidado no processo de Reforma Administrativa, quando se deseja mecanismos de controle que possam coibir e/ou reduzir essas práticas.

Pode-se lembrar que em 06 de dezembro de 1993, após o impeachment do Ex-Presidente Fernando Collor, foi criada uma Comissão Especial pela Presidência da República que tinha como essência a averiguação dos processos de corrupção que se alastravam na Administração Pública brasileira.

No relatório "A Comissão Especial e a corrupção na Administração Pública Federal", de dezembro de 1994, está o resultado dos trabalhos de investigação dos meandros da corrupção dentro da administração. O relatório é claro e confirma que em todos os lugares onde há circulação de recurso público, foram identificados problemas. O mecanismo indutor da corrupção está consubstanciado em diversos sistemas sofisticadíssimos, na qual a corrupção se transformou na "segunda natureza" do desempenho da máquina de poder. Esse aparato, revestido de graus crescentes de sutileza, se torna invisível ao controle governamental. Outro ponto a salientar foi que a Comissão identificou no sistema de pagamento do funcionalismo público federal um dos maiores focos de desmando e corrupção.

A corrupção na Administração Pública é vasta e abrange um leque grande de atividades e funções básicas do Estado. Sabe-se que a corrupção tem mostrado uma tendência de crescimento não só no Brasil, mas no mundo. Dessa forma, são necessárias análises mais profundas que as análises tradicionais do problema para se chegar a respostas adequadas. O Estado, necessário, deve atuar com uma política preventiva enérgica e com a maior severidade contra essa disfunção (Kliksberg, 1994). 
A necessidade de mecanismos de controle eficientes, também é conclusão do Relatório do Banco Mundial de 1997 para casos em que haja altos níveis de corrupção. O Estado é visto como a entidade capaz de revigorar o desenvolvimento nos países emergentes. Para isso, é necessário um Estado eficaz ajustado à sua capacidade e com instituições fortes.

\section{FLEXIBILIZAÇÃO: EFICIÊNCIA X E FICIENTISMO}

A Flexibilização da administração conseguida com elevação do grau de autonomia e descentralização de atividades é, sem dúvida, um benefício do ponto de vista puramente administrativo. Entretanto, na Administração Pública, deve ser vista com cautela pelas implicações políticas possíveis de redução da capacidade de controle.

Na Administração Pública, o processo de flexibilização pode ser encarado de duas formas. Uma, que se baseia no aumento da eficiência e que leva em conta apenas os benefícios administrativos desse processo. Outra, na qual, pode-se argumentar a idéia de eficiência como razão motivadora da flexibilização. Nesse caso, pode-se interpretar a busca por eficiência como sendo uma questão de eficientismo que é perseguido sem uma análise mais profunda do processo.

Osborne e Gaebler (1995), no livro Reinventando o Governo: como o espírito empreendedor está transformando o setor público, que é referência para o modelo gerencial, descreve os benefícios da flexibilização via descentralização das ações, implicando maior eficiência. A argumentação de Osborne e Gaebler (1995) traz a idéia de empreendedorismo na Administração Pública e do controle social, uma vez que a sociedade passa a ter uma atuação importante na fiscalização dos atos dos gestores públicos.

No entanto, outra forma de analisar o processo de flexibilização e descentralização é o colocado por Felicíssimo (1994). Para o autor, a descentralização pode ser vista de duas formas diferentes. Uma, na qual a descentralização envolve necessariamente a ampliação da cidadania. Porém, isto nem sempre vai além de um desejo que não se realiza. A segunda forma é justamente o contraponto desta concepção e, segundo o autor, decorre da pressão da ideologia eficientista que pensa apenas na resolução imediata dos problemas mais evidentes, restringindo o volume de demandas, resultado da participação nas decisões.

Putnam (1996), analisando a experiência de delegação aos governos regionais de mais poderes e recursos na Itália nos anos 70, mostra a importância do associativismo e da comunidade cívica, identificados como "Capital Social" , para o êxito e maior desempenho das instituições públicas e, consequentemente, para o desenvolvimento econômico. No Brasil, ao se pensar nas chances de uma atuação maior da sociedade, precisa-se investigar qual o "Capital Social" de que se dispõe para se vislumbrar as possibilidades de êxito no processo de flexibilização na qual é delegada mais autonomia e, consequentemente, mais poder e recursos às unidades descentralizadas.

\section{Sociedade Despreparada}

\section{Accountability: um Processo Cultural}

O controle efetivo do gasto público pressupõe uma democracia com participação social ativa e uma responsabilização dos gestores públicos (accountability) que precisa ser concebida dentro do contexto de nossa sociedade. O conceito de accountability é de fundamental importância para que se possa falar em participação social nas políticas públicas e responsabilização dos gestores públicos, ou seja, a idéia de controle social da Administração Pública. 
Segundo Campos (1990), accountability não é uma questão de desenvolvimento organizacional ou de Reforma Administrativa. A simples criação de controles burocráticos não se tem mostrado suficiente para tornar efetiva a responsabilidade dos servidores públicos. O grau de accountability de uma burocracia é explicado pelas dimensões contextuais da Administração Pública, por meio da textura política e institucional da sociedade, dos valores e costumes tradicionais partilhados na cultura e da própria história Quando as atividades governamentais se expandem e aumenta a intervenção do governo na vida do cidadão, a preservação dos direitos democráticos requer um controle efetivo da cidadania organizada; uma sociedade desmobilizada não será capaz de garantir a accountability.

Em países politicamente menos desenvolvidos como o Brasil, o exercício da democracia fica limitado à participação em eleições esporádicas, cujo traço característico é a aceitação passiva do domínio do Estado, refletido na negação do direito à educação básica gratuita para todos e do salário mínimo para os trabaIhadores. Assim, "Se a democracia fundamenta-se na soberania dos cidadãos, o modelo democrático experimentado no Brasil está longe de ser caracterizado como tal" (Campos, 1990).

Apesar de decorridos 10 anos das colocações da autora, ainda não se pode afastar essa visão do Brasil. A argumentação nos leva à necessidade de discutir a questão da democracia no Brasil, verificando as possibilidades de controle social que é uma forma de ampliação da democracia.

\section{A DEMOCRACIA NO BRASIL}

O controle social da Administração Pública se baseia em uma cidadania ativa. A ação da sociedade permitiria uma inserção social na Administração Pública capaz de garantir o cumprimento de programas do governo, viabilizando os projetos sociais e de interesse da nação. Entretanto, o que se percebe no Brasil é a cidadania não implantada. Os problemas decorrentes da crise econômica associados à corrupção e ao clientelismo incorporados à prática corrente na Administração Pública se sobrepõem às iniciativas inovadoras de governos locais, ou mesmo iniciativas do Governo Federal, de mecanismos de cidadania, tais como os Serviços de Atendimento ao Cidadão, fazendo com que essas iniciativas não tenham resultado em uma elevação do grau de cidadania no país que permita o controle efetivo dos recursos públicos.

O processo de construção da cidadania no Brasil tem características peculiares que se baseiam na história da consolidação dos direitos no ordenamento jurídico. Essa peculiaridade se situa na emergência de direitos sociais antes dos políticos e o frágil desenvolvimento dos direitos civis que têm causas na escravidão duradoura, cujos efeitos se fazem sentir até os dias de hoje, e, ainda, um Estado patrimonialista que resiste às mudanças estruturais (Pinho, 1997a).

O não estabelecimento de uma cidadania plena no Brasil se deve a fatores, tais como: a distância entre a democracia formal e a democracia real; a grave crise econômica que aumenta a recessão e produz um exército de desempregados sem perspectivas sociais; e, principalmente, devido a formação do Estado brasileiro ser baseada no modelo burocrático estamental patrimonialista, sendo marcado por um modelo híbrido (tradicional e moderno). Essa espécie de modelo híbrido interfere na cidadania mais ampla, mais disseminada, que visa ao futuro e não ao imediato. Há uma conveniência social onde o cidadão não exige e também não é exigido, relativizando-se a cidadania. Diante disso tudo, a cidadania fica reduzida, fora das relações contratuais legais, criando-se campo de relações próprias. Assim, não há possibilidades de se consolidarem os mecanismos legais de exercício do controle social dos recursos públicos.

Benevides (1994) faz algumas críticas à democracia representativa no Brasil e defende a tese de que devem ser colocados em prática os dispositivos institucionais de referendo, plebiscito e iniciativa popular, acolhidos na Constitui- 
ção Brasileira de 1988. Para ela, esses mecanismos de cidadania ativa podem-se mostrar, na pior das hipóteses, como um verdadeiro espaço de aprendizado de cidadania.

No Brasil, além do patrimonialismo inserido no seio do Estado, está a própria ineficácia da aplicação da lei. A certeza da aplicação da lei deveria ser o alicerce do Estado democrático de direito e o estímulo para utilização das possibilidades de controle da Administração Pública existentes no arcabouço jurídico. Entretanto, na democracia brasileira chega-se ao cúmulo de se falar na lei que "pegou" ou "não pegou", fazendo-se alusão ao fato de que muitos dispositivos legais são ignorados e/ou descumpridos sem haver punições.

Segundo Santos (1993), a ineficácia da aplicação da Lei no Brasil pode ser explicada pelo intenso processo de deslocamento social. Esta falta de eficácia normativa contamina toda a sociedade, inclusive as instituições e pessoas cuja designação é a preservação destas normas, tais como a polícia e o judiciário. No momento atual, esse quadro é agravado com a crise econômica que assola o país. Além disso, a necessidade de adequação institucional frente aos problemas enfrentados no campo do sistema financeiro internacional faz com que a sensação de vazio aumente, tornando a norma ainda mais inefetiva.

O'Donnell (1998), discute a própria aplicação do termo democracia para os Estados da América Latina. O autor analisa os casos onde a inefetividade da lei compromete os elementos básicos do conceito de democracia. O termo mais adequado, segundo o autor, seria poliarquias ou democracias políticas. São identificados, pelo autor, problemas como falhas na legislação existente, inefetividade na aplicação da Lei, dificuldades na relação da burocracia com os "cidadãos comuns", inacessibilidade ao Judiciário e a processos justos e, ainda, a ilegalidade pura e simples. Isto demonstra a dificuldade de se estabelecer um grau de accountability na democracia brasileira que permita a real garantia de controle de resultados.

$\mathrm{Na}$ democracia brasileira faltam elementos fundamentais que podem ser melhor entendidos com a separação teórica do conceito de accountability em dois níveis feito por O'Donnell (1998a): a accountability vertical e a horizontal. A accountability vertical refere-se às possibilidades de punição que surgem dos processos de eleições e reivindicações sociais que possam ser normalmente proferidas, sem que corra o risco de coerção, e cobertura regular pela mídia dos atos ilícitos de autoridades públicas. A accountability horizontal seria o fortalecimento dos componentes liberais e republicanos de muitas novas poliarquias.

O controle da Administração Pública, inserido nas instituições clássicas do Executivo, do Legislativo e do Judiciário, está intimamente ligado à accountability horizontal. Controlar os recursos públicos pressupõe a existência dos dispositivos adequados que são executados por agências legitimadas para tal ação.

A Reforma do Estado pode ser um ponto de partida para uma transformação da democracia do País. Entretanto, deve-se ter em mente que ela por si só não é suficiente. Przeworski (1998a), investigando mecanismos de democracia, buscou entender as possibilidades de democratização com a Reforma do Estado. Porém, ele conclui que a Reforma do Estado, mesmo sendo necessária, não é suficiente para superar as desigualdades políticas diante de desigualdades econômicas e sociais.

\section{Controle Social no Momento Atual do Processo de Reforma}

As possibilidades de melhoria do padrão de controle social sobre a Administração Pública brasileira emergem da análise de todos os fatos discutidos anteriormente. Alguns ideais do gerencialismo que elevariam a participação social não se tornaram efetivos até o momento e a realidade social brasileira dificulta a solução do problema. Entretanto, há caminhos que podem ser trilhados, reconhecendo-se as dificuldades existentes e perseguindo-se o ideal democrático. São as- 
pectos que do ponto de vista prático da reforma administrativa não se consubstanciaram em medidas mais agressivas e estratégias de ação direcionadas para induzir um processo que viabilize o controle social adequado num Estado realmente moderno.

\title{
A ValorizaçÃo do Controle
}

\author{
SOCIAL NA ESTRATÉGIA DE M UDAN ÇA
}

O processo de votação do Plano de Reforma Administrativa no Congresso Nacional foi profundamente marcado pela condições econômicas do País. Acabouse por privilegiar os aspectos relacionados à desburocratização, à flexibilização e à redução de custos em detrimento de outros aspectos tais como transparência, accountability, ética, profissionalismo, competitividade e enfoque no cidadão, todos relacionados ao controle social, como descritos por Pimenta (1998,1998a). O Congresso aprovou as medidas colocadas sem uma discussão mais apurada da transformação. O problema, decorrente do resultado das transformações práticas da Reforma, é que a desburocratização, a flexibilização e a redução de custos, implantadas no curto prazo, podem-se transformar em gastos com impropriedades e com aumento da corrupção a longo prazo.

No momento atual, já ocorreu a fase inicial de fixação do ideário da Reforma. O que se pode verificar é que do início da reforma até agora alguns pontos se tornam esquecidos, como é o caso das Organizações Sociais e Agências Executivas que quase não saíram do papel. Enquanto outros têm sido introduzidos continuamente, transformando a formatação da Administração Pública, como é o caso do modelo de Agências reguladoras.

Do ponto de vista estratégico, ainda há espaço para valorização do controle social dentro da transformação gerencial em curso. São urgentes e necessárias ações específicas nesse campo. Por exemplo, trazendo-se à tona a discussão sobre a legislação referente ao controle no Brasil. Discutir os dispositivos legais e mecanismos institucionais que versam sobre controle dos gastos públicos é a própria discussão dos meios para controle social pois é onde mais precisamos avançar. O Governo Federal tentou fazer isso introduzindo o projeto Brasil Transparente, porém de uma forma não orientada e com medidas impositivas sobre os órgãos estabelecidos de Controle (Tribunais de Contas e Sistemas de Controle Interno) e com único objetivo de responder à sociedade aos casos de denúncia que surgiam em 1999. Desse contexto, se conclui que é preciso se realizar uma discussão ampla dos dispositivos legais e normativos com participação de todos os interessados.

\section{Canais de Atuação para Controle Social}

O controle social necessita de dispositivos formais de atuação da sociedade e, ainda, que esses dispositivos sejam ágeis e amplamente conhecidos. Porém, todos sabem que mesmo as camadas mais privilegiadas da nossa sociedade não têm o conhecimento suficiente de como funciona a máquina pública. Os procedimentos são obscuros e não há publicidade adequada dos atos que afetam diretamente as comunidades. Mesmo quando há publicidade, os mecanismos de atuação existentes não têm sido suficientes para impedir e/ou coibir abusos.

O desenvolvimento de controles sociais eficientes para o controle da Administração Pública requer um projeto de educação de massa de longo prazo, além de mecanismos legítimos e conhecidos (Di Pietro,1998a).

Segundo Ribeiro (1997), a Reforma Administrativa, no Brasil, não é um fenômeno isolado. Simultaneamente, existem fatores de ordens diversas que influenciam a condução dos negócios. Num contexto democrático e de revolução 
tecnológica, se fazem necessários um esforço de adequação institucional e uma reflexão mais profunda sobre o papel do controle nas organizações públicas, em qualquer que seja o tipo de controle utilizado: preventivo (corretivo e mecanicista) ou quer na linguagem do paradigma gerencial (flexível).

O controle pode ser encarado, também, como um processo de descentralização do poder. Para Bittar e Coelho (1994), o processo de descentralização do poder implica proposta de constituição de conselhos populares, canais institucionais de participação e reconhecimento dos diversos atores sociais na construção de uma esfera pública democrática. São necessários, para tanto, canais de participação individuais, combinados com um processo de informação mediante a informatização, transparência e estímulo aos cidadãos para intervirem coletivamente na definição, execução e controle das políticas públicas.

A participação democrática pode ser entendida de várias formas, mas o novo espaço que se tem apresentado são os canais de participação na gestão local, que consistem em espaços " institucionalizados (conselhos) ou não " criados na esfera local, com vistas a serviços de ponte entre o Estado e a sociedade. Em regra, a radicalização da partilha do poder envolve conceder aos cidadãos participação real e não apenas consulta. O orçamento participativo aparece como essa espécie de radicalização em que é concedido real poder de decisão àqueles que tomam parte dele (Daniel, 1994).

Entretanto, segundo Cunill Grau (1996), deve-se ter cuidado na geração de mecanismos de participação social. A institucionalização da participação pode não estimular a organização social e, em contrapartida, vir a se constituir em uma desarticulação do tecido social e fortalecer as assimetrias da representação social, redundando no enfraquecimento da sociedade civil. Apesar disso, a autora fala que é necessária a criação de uma discriminação positiva para envolvimento dos atores interessados.

Para o Governo tornar realidade as decisões que toma, ele necessita de um sistema de controle que corrija os rumos para se alcançar os objetivos. Assim, o conceito de governance, colocado por Diniz $(1997,1998)$, parece ser mais adequado para enfocar o problema quando a autora inclui o conjunto de mecanismos e procedimentos para lidar com a dimensão participativa e plural da sociedade, o que implica expandir e aperfeiçoar os meios de interlocução e de administração do jogo de interesses.

O que se pode concluir desse quadro é que faltam vias de atuação. O cidadão comum não sabe como atuar e tem medo de exercer a sua cidadania por falta de informação e receio das repercussões que possam advir dos seus atos. Para reduzir essas incertezas, é preciso viabilizar canais formais de acolhimento de denúncias e disponibilização de informação simples, consistente e por meio de regras claras. Podem ser criadas, por exemplo, Ouvidorias, com procedimentos processuais definidos, prazos e mecanismos de divulgação das ações, nos sistemas de Controle Interno dos órgãos governamentais, que do ponto de vista de controle são os órgãos mais próximos ao local da execução dos recursos.

Por outro lado, estando a sociedade despreparada, não se pode imaginar que vai haver comprometimento na ação de controle. É necessário um projeto de longo prazo de educação da sociedade com introdução, se possível, de matéria no currículo dos alunos de $1^{\circ}$ e $2^{\circ}$ graus. Portanto, estaremos construindo uma sociedade mais informada e consciente de seus direitos e obrigações.

Outro problema a ser pensado, é a eficácia dos Conselhos Municipais e Estaduais como agente de controle social. Sabemos que se torna difícil em pequenos municípios fugir da cooptação política dos membros desses Conselhos pelos Prefeitos. Assim, é imprescindível investigar outras possibilidades de controle dentro desse modelo. O investimento em formação de membros de Conselhos é uma saída para o problema técnico que deve ser mais explorada, porém não resolve a questão política. Esta questão depende de processo de longo prazo e também pode ser reduzido pelo desenvolvimento social decorrente do processo educativo da sociedade. 


\section{A Questão da Cultura no Serviço Público}

A cultura de clientelismo e de patrimonialismo dentro das organizações públicas associadas a uma falta de capacitação de servidores são um problema para o estabelecimento de flexibilidades na administração. Segundo Schwartzman (1996), a visão moderna da administração parte do princípio de que o administrador é honesto até prova em contrário, dá ampla flexibilidade de ação para os dirigentes das organizações e substitui os controles formais pela avaliação de resultados. Porém, os controles formais continuam existindo pelo fato de que a simples eliminação das restrições e controles burocráticos não é suficiente para garantir o bom desempenho e a correção no uso dos recursos públicos por parte das instituições governamentais. Nesse problema, tem-se dois pontos chaves: o desempenho e o controle. O primeiro é marcado pela cultura e depende do mercado e das profissões que se exerce. Mercado e profissões dentro do jogo econômico são mais fáceis de se criar, enquanto cultura faz parte de um processo de longa duração. O segundo problema diz respeito ao controle, cujos órgãos oficiais, Tribunais de Contas e Secretarias de Controle Interno, pecam pela falta de capacidade técnica e legitimidade para exercer a função.

O problema da cultura só pode ser resolvido a longo prazo. Enxerga-se, nesse campo, pelo menos dois caminhos que poderão viabilizar uma transformação na cultura da Administração Pública brasileira. Um deles é o decorrente dos programas de capacitação e treinamento internos. O segundo decorre da modificação na cultura conseguida pelos ingressos de novos servidores mediante concursos públicos e a restruturação das carreiras públicas. A renovação de pessoal provoca uma verdadeira alteração de costumes e condutas dentro da administração, porém esse é um processo lento. Durante muito tempo se privilegiou o apadrinhamento e o nepotismo na administração brasileira. Isto criou uma verdadeira chaga difícil de se extirpar porque se reproduz ao contaminar outros servidores que se tornam impotentes num sistema tão complexo.

Nesse ambiente, fortemente marcado por vícios culturais, temos certeza que os programas de capacitação e a renovação por meio de concursos públicos são uma possibilidade efetiva de melhoria do controle da Administração Pública. No caso da capacitação é preciso recursos suficientes e continuidade. A possibilidade de modificação da cultura dentro da administração, reduzindo as raízes patrimoniais, implica, sem dúvida alguma, melhora das condições para o controle social.

\section{DESENVOLVIMENTO DE INDICADORES:}

Outro ponto a analisar, refere-se à avaliação de desempenho das ações do Estado. Os contratos de gestão tornam-se peça muito importante, pois a relação entre as entidades de prestação de serviços descentralizados e o Estado dar-seão basicamente por esse tipo de contrato após a Reforma. Os controles passam a se restringir aos parâmetros que foram negociados nos contratos de gestão e, dessa forma, é importante verificar as possibilidades efetivas de convergência com o interesse público. Não se pode apenas mostrar os exemplos positivos e esquecer de avaliar com muita atenção as possibilidades de deficiências, principalmente, se essa ferramenta passar a ser o instrumento de definição de parâmetros de controle. Podem surgir diversas dificuldades na elaboração de contratos de gestão, tais como: o que significa resultado para a Administração Pública?; quais devem ser os parâmetros de controle?; os conselhos não poderiam ser cooptados?; existirá capacitação técnica para exercer a atividade de fiscalização?; qual deve ser o fluxo financeiro para as entidades de prestação de serviço descentralizado?

Santos e Cardoso (2001) desenvolveram um brilhante estudo sobre avaliação de desempenho no contexto brasileiro, analisando detalhadamente a legislação envolvida, comparando o caso do Brasil com outros países e evidenciando 
as dificuldades inerentes aos modelos atualmente propostos. Este estudo aponta para a necessidade de uma reavaliação do caminho trilhado pelo Brasil, considerando-se as diferenças insuperáveis entre o setor público e o setor privado.

Do ponto de vista do Direito Administrativo, o contrato de gestão assume um papel enigmático, pois como imaginar uma relação contratual do Estado para com ele mesmo, nos casos das agências autônomas? Existem dúvidas da possibilidade de existência de um pacto jurídico entre órgãos e entidades da administração direta e indireta com o poder público. Esses contratos fogem aos traços nucleares da consensualidade e da autoridade dos termos (Lammêgo, 1998).

Ramos (1997) recomenda a necessidade de se adotar as medidas sugeridas pela teoria do agent-principa/ ${ }^{3}$ a fim de se enfrentar os problemas de adequação da estrutura de incentivos e da efetivação do controle social. Além disso, deve-se levar em conta o processo de negociação dos instrumentos e os sistemas de aprendizado na Administração Pública com ênfase na capacitação do núcleo estratégico.

Independentemente do contrato de gestão, o que se está discutindo é a possibilidade de avaliação do desempenho do agente público. Analisando-se as medidas do governo americano para implementação do modelo gerencial, vê-se que muitas medidas foram tomadas no sentido de desenvolver os indicadores de desempenho por meio de um corpo gerencial no nível federal do governo. Os sistemas de orçamento foram adequados para permitir os controles via indicadores de desempenho (Cavalcanti e Otero, 1997). Nota-se, assim, que são necessárias condições preliminares para efetivação das mudanças. O processo de controle depende de indicadores e sistemas que funcionem para então se aumentar a flexibilidade de forma gradual.

Desses fatos, pode-se inferir que tanto para os Órgãos públicos, quanto para os programas de governo de natureza continuada, é necessário o desenvolvimento de indicadores de desempenho. Além disso, para que a sociedade possa interferir no processo, é necessária a divulgação em linguagem clara. Muito temse falado sobre a necessidade de indicadores e pouco tem sido feito efetivamente nesse campo. Os indicadores de desempenho é que permitem tanto à sociedade, quanto ao próprio governo e aos órgãos de Controle a aferição da consecução dos objetivos e metas.

No caso da gestão dos órgãos do governo, para se desenvolver indicadores, deve-se ter a premissa de que muitos têm funcionamento similar e não se pode deixar a questão na mão de cada gestor de recursos individualmente, como previsto na Instrução Normativa no 12 do Tribunal de Contas da União que dispõe sobre Tomada e Prestação de Contas. É preciso uma estratégia de desenvolvimento de indicadores de forma centralizada e uniforme, com conexão vertical e horizontal, buscando-se, sempre que possível, indicadores comuns aos diversos órgãos. Por exemplo, Delegacias da Receita Federal de Julgamento devem-se basear nos mesmos indicadores, permitindo um padrão de comparação de eficiência, eficácia e economicidade. Assim também pode-se pensar para Delegacias de Polícia Federal e outras Delegacias e Gerências que tenham funcionamento similar. Além disso, é preciso que esses indicadores, sempre que possível, sejam gerados dentro dos sistemas informatizados disponíveis os quais já possuem toda a informação necessária, tornando a sua obtenção e acompanhamento mais ágil e confiável. Algum avanço já está sendo desenvolvido nessa área por meio das Decisões 358/2000 e 408/2002 do Tribunal de Contas da União especificamente para às Instituições Federais de Ensino, porém ainda temos um longo caminho pela frente.

\footnotetext{
3 Przeworski (1998) faz uma discussão da teoria agent $x$ principal no texto "Sobre o desenho do Estado uma perspectiva agent x principal", recomendando para reduzir os problemas das burocracias públicas: formulação de contratos adequados; triagem e seleção para recrutamento no serviço público; fiscalização institucional; criação de múltiplos principals ou múltiplos agents; estabelecimento de competição entre agências estatais e descentralização.
} 
No caso dos programas de longa duração, os indicadores devem permitir o controle eficiente do programa. Para isso é necessário pensar que qualquer programa deve ter na sua legislação básica instrumentos eficientes de controle. A regra no Brasil tem sido a criação de vários programas nos quais posteriormente a sua concepção e definição da legislação básica, e, quase sempre, durante a sua fase de execução, busca-se meios para o controle sem disponibilidade de indicadores consistentes e instrumentos de controle eficazes, não permitindo a avaliação efetiva desses programas. Assim, pode-se concluir que é necessária uma participação atuante dos órgãos de controle na elaboração desses dispositivos legais, viabilizando os instrumentos necessários ao controle social já na concepção dos programas novos. No caso dos programas em curso, seria importante uma reavaliação e proposição de alterações na legislação básica que contemplasse instrumentos mais eficazes de acompanhamento e controle.

\section{U NIFORMIZAÇÃO E INTEGRAÇÃO DOS}

\section{Sistem AS de In Form AÇÃO de CONTROLE}

Finalmente, vale colocar aqui um breve comentário sobre as grandes possibilidades de controle via sistemas informatizados. A informação é um elemento básico para o controle social e, pelo volume de dados presentes nos processos do governo, isso só pode ser conseguido via informatização. Independente da mudança estrutural proposta, a Reforma Administrativa traz a intenção de fortalecimento dos sistemas informatizados de gestão pública que desempenham controles sobre a administração financeira, orçamentária, patrimonial e de pessoal, a exemplo do SIAFI, SIASG, SIDOR, SISPLAN e SIAPE e outros sistemas que estabelecem dispositivos de sistematização que não existiam e são fundamentais para o controle efetivo. Esses sistemas visam à centralização das informações que abrangem diversas áreas: pessoal civil, serviços gerais, organização e modernização administrativa, informação e informática, planejamento e orçamento e controle interno do Governo Federal. Essa é uma medida de importância imensurável no contexto de controle dos recursos públicos. Os controle formais, antes exercidos com normas e procedimentos escritos, agora passam a ser padronizados nos sistemas informatizados, tornando-se arma poderosa no acompanhamento dos resultados.

A Internet se apresenta, também, como um canal importante para o controle efetivo das ações e projetos das instituições públicas (Sato, 1997). Isto também é indicado por Pimenta (1998) que vê no progresso da tecnologia de informação e no avanço das mídias de massa, como a Internet, uma real possibilidade de aumento da participação social na formulação das políticas, na definição do gasto público e nos processos legislativos e judiciário. A informatização intensiva do setor torna-se a grande arma dos sistemas de controle e, para isso, é preciso uma grande vontade política, pois essa opção depende de investimentos para viabilizar mecanismos de controle social estruturados com base em informação proporcionada por esses sistemas.

Informação é a base para qualquer sistema de controle. A uniformização dos sistemas de informação utilizados pelos diversos agentes que atuam na área de controle deve ser a meta. Falar a mesma linguagem para a população significa melhorar as possibilidades de controle social. Hoje há superposição de tarefas e dispersão de dados, causando apatia e desconfiança por parte da sociedade. Cada agente controlador (Controle Interno, TCU, TCE, TCM e etc) tem o seu site na Internet com informações pouco acessíveis ao cidadão comum. O ideal seria a criação de um sistema de informação comum, disponível na Internet e por outras vias de divulgação e recolhimento de demandas, tendo por exemplo os Correios como instrumento local, tipo um portal do cidadão, com a participação dos diversos agentes, propiciando informações claras da execução dos gastos públicos e disponibilizando canais de atuação seguros e ágeis. 


\section{CONSIDERAÇÕES FINAIS}

As propostas de ação previstas nesse trabalho não pretendem esgotar o tema, ao contrário, busca-se alertar para a necessidade de uma discussão direcionada, tendo-se como base a importância do controle social dentro das perspectivas vislumbradas.

Por último, ressalte-se que quando se pretende melhorar condutas é preciso investigar as suas falhas, identificar as causas e propor as soluções inovadoras e consistentes com a realidade apresentada. É urgente a necessidade de medidas mais eficazes de reforma da administração para se atender aos interesses da sociedade e permitir maior participação nos processos de execução do gasto público.

Os sistemas de controle precisam de uma discussão mais profunda, pois a sociedade brasileira não suporta mais as soluções fáceis de aumento da carga tributária e das transformações que buscam objetivos eleitorais e/ou acordos de interesse meramente econômicos. Os traços histórico-culturais, que reduzem a capacidade de efetividade da Administração Pública no Brasil, são muito fortes. Porém, a solução reside na construção de um controle baseado no desenvolvimento social apoiado na educação e no trabalho.

A discussão aqui apresentada tem um caráter de crítica positiva, identificando não só as dificuldades, mas tentando averiguar possibilidades efetivas, visando, assim, dar subsídios para o estabelecimento de práticas compatíveis com a ética e a justiça social. Espera-se que dessa forma se esteja ajudando a reformar a administração para a sociedade.

\section{REFERÉnCIAS BIBLIOGRÁfICAS}

ABRUCIO, Fernando Luiz. O impacto gerencial na Administração Pública: Um breve estudo sobre a experiência internacional recente, Cadernos ENAP № 10, Brasília,1997.

BANCO MUNDIAL. Relatório sobre o Desenvolvimento Mundial - O Estado num Mundo em Transformação, Panorama Geral, Oxford University press, inc, Jun,1997.

BITTAR, J. E Coelho, F. D. Gestão democrática, Inversão de prioridades e os caminhos da Administração Pública municipal. In: Ribeiro, L. C. e Santos JR, O. A. (Orgs.) Globalização, Fragmentação e Reforma Urbana. Rio de janeiro, Civilização Brasileira, 327-350, 1994.

BRESSER PEREIRA, Luiz Carlos. Estratégia e estrutura para um novo Estado, Revista do Serviço Público, 48(1):5-25, Jan./Abr. 1997.

Reforma do Estado para a cidadania - A Reforma Gerencial brasileira na perspectiva institucional, ENAP, Editora 34, BrasíliaDF, 1998.

CAMPOS, Ana Maria. Accountability: quando poderemos traduzi-la?, Revista de Administração Pública, Rio de janeiro, FGV, 24(2), fev./abr./1990.

CAVALCANTI, Bianor Scelza e OTERO Roberto Bevilacqua. Novos padrões gerenciais no setor público: medidas do governo americano orientadas para o desempenho e resultados. Texto para Discussão no 16, Brasília. MARE/ENAP, 1997

CUNILL GRAU, N. C. A rearticulação das relações Estado-sociedade: em busca de novos significados, Revista do Serviço Público, Ano 47, 120(1):113-137, Jan./ Abr. 1996.

DANIEL, C. Governo Local e participação da sociedade, Villas-Boas, Renata (org.) Participação Popular nos Governos Locais, São Paulo, Polis, (14):21-42, 1994. 
DINIZ, ELI. Em busca de novo paradigma: A Reforma do Estado no Brasil dos anos 90, in: Crise, Reforma do Estado e Governabilidade, Eli Diniz, Rio de janeiro, Editora Fundação Getúlio Vargas. 1997.

Governabilidade, democracia e Reforma do Estado: Os desafios da construção de uma nova ordem dos anos 90, in: Diniz, Eli e Azevedo, Sérgio de. Reforma do Estado e democracia no Brasil, Brasília. Editora Universidade de Brasília, 1998.

DI PIETRO, Maria Sylvia Zanella. Direito Administrativo, 9a Edição, São Paulo, Atlas, 1998.

Cidadão e sua defesa. A "Res pública" e sua defesa, Trabalho apresentado no Seminário Internacional - Sociedade e a Reforma do Estado, São Paulo, 26 a 28 de Março,1998a.

EDELMAN, Hugo e APARÍCIO, Rafael El Control Interno em las empresas del Estado, 2 ${ }^{a}$ Ed. Montevideo, Programa Nacional de Desburocratization, 104p, 1992.

ENAP/MARE Histórico das Reformas Administrativas no Brasil e tendências e inovações em nível internacional (perspectivas do governo Fernando Henrique Cardoso), Centro de Documentação, Informação e Difusão Graciliano Ramos, Brasília-DF, 1995.

FELICÍSSIMO, José Roberto. América latina : movimentos sociais frente à descentralização do Estado, Revista de Administração Pública, Rio de janeiro, 28(3):26-43, Jul./Set. 1994.

KLIKSBERG, Bernardo. La Reforma de La Administración Pública en América latina, Colección: Administración Pública en América Latina, Instituto Nacional de Administración Pública, Alcala de Henares, 1984.

Redesenho do Estado para o desenvolvimento sócioeconômico e a mudança: uma agenda estratégica para a discussão, Revista da Administração Pública, Rio de janeiro, 28(3):5-25, Jul./Set., 1994.

KLITGAARD, Robert E. A corrupção sob controle, tradução de Otávio Alves Velho, Rio de Janeiro, Editora Jorge Zahar, p.9-10, 1994.

LAMMÊGO, Uadi Bulos. Reforma Administrativa (Primeiras impressões), BDABoletim de Direito Administrativo, Doutrinas, Pareceres e Atualidades, 704-725, Nov/1998.

LaPIERRE, Richard T. A Theory of Social Control, McGraw-Hill series in Sociology and Anthropology, New York/Toronto/London, 1954.

LOUREIRO, Maria Rita e FINGERMANN, Henrique Mudanças na Relação públicoprivado e a problemática do controle social: Algumas reflexões sobre a situação Brasileira in: Parceria Público/Privado- Cooperação Financeira e Organizacional entre o Setor Privado e as administrações Públicas Locais. Lodovici, E., Bernareggi, G., Fingerman, H. (org). Vol. I, Sumus Editora, São Paulo, 1992.

MARTINS, Humberto Falcão Burocracia e a revolução gerencial - a persistência da dicotomia entre política e administração. Revista do Serviço Público, Ano 48, 1:43-79, Jan./Abr. 1997.

MEIRELLES, Hely Lopes. Direito Administrativo Brasileiro, 20a Edição, Atualizada por Eurico de Andrade Azevedo, Délcio Balestero Aleixo e José Emmanuel Burle Filho, Malheiros Editores, São paulo, 569-627, 1995.

MINISTÉRIO DA ADMINISTRAÇÃO E REFORMA DO ESTADO. Plano Diretor da Reforma do Aparelho do Estado, Imprensa Nacional, novembro 1995, Plano aprovado pela Câmara da Reforma do Estado da Presidência da República em setembro de 1995. 
NASSUNO, Marianne Organização dos usuários: participação na gestão e controle das organizações sociais. Revista do Serviço Público, Ano 48, 1:43-79, jan./ abr. 1997.

NOGUEIRA, Marco Aurélio. A crise da gestão pública: Do reformismo quantitativo a um caminho qualitativo de reforma do Estado, Cadernos Fundap, 25:6-25, 1997.

O 'DONNELL, Guilhermo. Poliarquias e a (in)efetividade da lei na América Latina, Novos Estudos CEBRAP, 51:37-61, Jul.,1998.

Nova, 44:26-54, 1998a.

Accountability horizontal e novas poliarquias, Lua

OSBORNE, David. e GAEBLER, Therborn. Reinventando o Governo: Como o Espírito empreendedor está Transformando o Setor Público. Brasília. MH Comunicação. 1995.

PENTEADO FILHO, Paulo de Arruda. Desafios e oportunidades da Reforma do Estado no Brasil: A questão das organizações sociais, Organizações e Sociedade, Escola de Administração da UFBA, 5(11)153-168, Jan./Abr., 1998.

PIMENTA, Carlos César. Descentralização com integração: A gestão de políticas públicas em um contexto descentralizado - $O$ caso Brasileiro, Texto preparado para o III Congresso Internacional do CLAD - Conselho Latino-Americano para o Desenvolvimento - sobre a Reforma do Estado e da Administração Pública, Madrid, 14-17 de Outubro, 1998.

A Reforma Gerencial do Estado brasileiro no contexto das grandes tendências mundiais, Revista de Administração Pública, Rio de Janeiro, 32(5):173-199. Set./Out., 1998a.

PINHEIRO, Paulo Sérgio e VIEIRA, Oscar Vilhena Prefácio: Corrupção, a morte anunciada dos governos in: Itália: Operação mãos limpas / E no Brasil? Quando? José Luiz Del Roio, tradução: Anízio de Oliveira, São Paulo, Editora Ícone, p9-19, 1993.

PINHO, José Antônio Gomes de. Corrupção: uma taxonomia tentativa, Trabalho apresentado na 21aㅡ Enanpad - Encontro Anual da Associação Nacional dos Programas Pós-graduação em Administração, Set./1997.

e Outros. Gestão Pública em Busca de Cida-

dania: Experiências de Inovação em Salvador, Revista da Escola de Administração da UFBA, 4(8):57-90, Abril, 1997a.

Patrimonialismo, Burocracia e Gerencialismo:

um "mix" possível?, Trabalho apresentado no Seminário Internacional - Sociedade e a Reforma do Estado, São Paulo, 26 a 28 de Março, 1998.

Reforma do Aparelho do Estado: Limites do gerencialismo frente ao patrimonialismo, Organizações e Sociedade, Escola de Administração da UFBA, 5(12)59-79, Maio./Agosto, 1998a.

PRESIDÊNCIA DA REPÚBLICA - COMISSÃO ESPECIAL. A comissão especial e a corrupção na Administração Pública Federal. Relatório da comissão especial criada pelo Decreto 1001 de 6 de dezembro de 1993, Brasília Dezembro, 1994.

PRZEWORSKI, Adam. Sobre o desenho do Estado: Uma perspectiva agent x principal. in: Reforma do Estado e Administração Pública Gerencial, Orgs. Bresser Pereira, Luiz e Spink, Peter., Rio de janeiro. Editora Fundação Getúlio Vargas, 1998.

The State and the citizen. Trabalho apresentado no Seminário Internacional - Sociedade e a Reforma do Estado, São Paulo, 26 a 28 de Mar/1998a. 
PUTNAM, Robert D. Comunidade e Democracia: A experiência da Itália moderna, Tradução de: Making Democracy work: Civic traditions in moden Italy (Princeton University Press, 1993), por: Luiz Alberto Monjardim. Rio de Janeiro, Editora Fundação Getúlio Vargas, 1996.

RIBEIRO, Sheila Maria Reis. Controle interno e paradigma gerencial, Texto para Discussão no-17, Brasília: MARE/ENAP, 1997.

RAMOS, Marcelo de Matos. Contratos de Gestão: instrumentos de ligação entre os setores do aparelho do Estado, Revista do Serviço Público, Ano 48, 2:81-100, Mai./Ago./1997.

SATO, Cláudio Seiji. Utilizando a internet na Administração Pública, Textos para discussão no 22, Brasília, MARE/ENAP, Dez/1997.

SANTOS, Luiz Alberto dos e CARDOSO, Regina Luna dos Santos. Avaliação de Desempenho da Ação Governamental no Brasil: Problemas e Perspectivas, Trabalho apresentado e vencedor do $1^{\circ}$ Lugar no XV Concurso de Ensayos del CLAD "Control y Evaluación del Desempeño Gubernamental", Caracas, 2001

SANTOS, Wanderley Guilherme dos. Razões da Desordem, Rio de Janeiro, Rocco, 1993.

SCHWARTZMAN, Simon. Bases do Autoritarismo Brasileiro, Rio de janeiro, Campus, 1988.

Desempenho e controle na Reforma Administrativa,

Textos para discussão no 8, Brasília, MARE/ENAP, Set/1996.

SHERPED, Geofrey e VALENCIA, Sofia. Modernizando a Administração Pública na América Latina: problemas comuns, sem soluções fáceis, Revista do Serviço Público, Ano 47, 120(3):101-128, Set-Dez/ 1996.

VIEGAS, Waldyr. Controle administrativo e controle social - Analogias, contrastes e paralogismos, Cadernos de Administração, Ano II, oo 6, Departamento de Administração da Universidade de Brasília, Brasília-DF, Out./Dez. 1996. 